\title{
The Effectiveness of Proprioceptive Neuromuscular Facilitation in Regards to the Improvement of Motor Control in Lower Limbs, Post-Immobilization
}

\author{
Popa Cristina-Elena ${ }^{1}$ \\ 1"Vasile Alecsandri" University of Bacău, 157, Calea Mărășești, 600115, Romania
}

Keywords: trauma, sequelae, mobility, stability, ability

\begin{abstract}
The immobilization in a cast causes perturbations in the circulation, muscle distortion, retraction of the ligament capsule and adherences. The aim of this paper is to particularize certain methods and techniques to diminish the post-immobilization sequelae in the lower limbs. The group of subjects comprised 8 patients with knee injuries, the study being conducted over the course of 10 months. The assessment methods consisted in using tests for mobility, strength, stability and ability. The physical therapy intervention consisted in multiple methods and techniques that, over the course of the treatment were particularized according to the symptoms of the patients. The general conclusion that can be extracted from this study is that the use of proprioceptive neuromuscular facilitation in the lower limbs, during the post-immobilization phase, has beneficial effects on the patients' health, shortening their rehabilitation period, reducing the risk of complications and contributing to the consolidation of the positive results.
\end{abstract}

\section{Introduction}

Amongst all knee joints, the most frequently injured are the medial collateral ligament and the anterior cruciate ligament. The most frequent mechanism that injures the knee ligaments is a medial inward force, usually accompanied by an external rotation and flexion (Johnston, 2006, p. 2571). In such cases, the medial collateral ligament is usually injured, followed by the anterior cruciate ligament, and then by the medial meniscus.

The second most frequent injuring mechanism is an external force affecting usually the medial collateral ligament, the anterior cruciate ligament or both. The anterior or posterior forces and the hyperextension usually result in the injury of anterior cruciate ligaments. Weight carrying and rotation at the moment of injury predispose to meniscus injuries (Simon, 2006, p. 2572). Two-three weeks of immobilization can cause muscle mass loss up to $5-10 \%$ associated with a strength decrease up to 10-20\% (de Boer et al., 2007, p. 241; Glover et al., 2008, p. 6050).

Sommer mentions a study on the importance of muscles around the knee for the static and dynamics of the whole body. The author proved through the measuring of the knee muscle strength in various body positions the great influence 
of the cervical area, pelvic area and especially the thoracic and lumbar area on the body movement (Sommer, 1988, p. 387). Saltin and Gollnick (2011) proved that "after a few weeks of training, modifications occur in the properties of muscle fibers, which means changes in their typology. Reversely, under pathological conditions (e.g. heart failure) there is muscle deconditioning due to the absence of a certain level of physical activity that translates in the increase of type II (b) fibers" (Sullivan, Green, \& Cobb, 1990, p. 520).

Muscle strength is only indirectly a function of the type of muscle fiber, in the sense that some fibers have larger diameters, with more myofibrils, thus less transversal bridges (Sbenghe, 2008, p. 196). A quick and effective rehabilitation of the muscle mass and strength is crucial for the patients in the post-immobilization period (Hvid et al., 2010, p. 1630), even though there is a small number of studies regarding the molecular influence on the muscle mass in this phase (Jones et al., 2004, p. 1025).

Active physical therapy used to rebuild muscle strength, not only in the quadriceps but also in the hamstrings, is becoming less and less analytical and more global, directed in the sense of rebuilding the lower limb muscle fibers. The work is done on an open muscle chain, against a manual resistance and using fully the peripheral and central neuromuscular facilitation elements (Kiss, 2002, p. 160). Thus, by knowing the exciting flows converging toward a group of motor neurons that contract a certain muscle, and by also using the nearby stimulating sources, one can strengthen their response, and increase the time of the membrane potential from $0.5-1 \mathrm{~ms}$ to $10-15 \mathrm{~ms}$. This is what happens in the proprioceptive neuromuscular facilitation methods (Kabat \& McLeod, 1959).

\section{Material and methods}

The hypothesis that started this study was: if the application of proprioceptive neuromuscular facilitation (PNF) techniques in treating the lower limb postimmobilization sequelae contributes to the improvement of motor.

The research was conducted on a group of 8 male subjects diagnosed with knee ligament tears that needed surgery. The immobilization in these cases was done with adjustable orthoses, and the physical therapy intervention has started approximately two-three weeks after the surgery. As one can see in Table 1, the patients were selected from various social environments, being of a close age, each of them benefiting from 12-15 physical therapy sessions until the complete rehabilitation of their motor control, performed three times per week, with one or two days break between them, to prevent muscle fatigue.

During the break, the patients performed an exercise program adapted to each one's symptoms. The methods and techniques applied during the treatment were carefully particularized and individualized according to the subjects' reactions, both during and over the course of the treatment or sessions. 
Table 1. The group of subjects

\begin{tabular}{|c|c|c|c|c|c|}
\hline No. & Initials & Gender & Age & Clinical diagnosis & Profession \\
\hline 1. & B.D. & M & 38 & $\begin{array}{l}\text { Left knee anterior cruciate } \\
\text { ligament with sprain and partial } \\
\text { tear (Operated) }\end{array}$ & $\begin{array}{l}\text { Computer } \\
\text { operator }\end{array}$ \\
\hline 2. & M.I. & M & 42 & $\begin{array}{l}\text { Right knee anterior cruciate } \\
\text { ligament injury, patella tear } \\
\text { (Operated) }\end{array}$ & Public clerk \\
\hline 3. & R.A. & M & 35 & $\begin{array}{l}\text { Proximal deinsertion of the right } \\
\text { knee anterior cruciate ligament } \\
\text { (Operated) }\end{array}$ & Works in sales \\
\hline 4. & G.G. & M & 40 & $\begin{array}{l}\text { Left knee anterior cruciate } \\
\text { ligament tear (Operated) }\end{array}$ & Sales person \\
\hline 5. & M.E. & M & 35 & $\begin{array}{l}\text { Left knee anterior cruciate } \\
\text { ligament tear (Operated) }\end{array}$ & Manager \\
\hline 6. & V.A. & M & 36 & $\begin{array}{l}\text { Right knee anterior cruciate } \\
\text { ligament tear (Operated) }\end{array}$ & Electrician \\
\hline 7. & M.A. & M & 43 & $\begin{array}{l}\text { Left knee anterior cruciate } \\
\text { ligament tear (Operated) }\end{array}$ & Architect \\
\hline 8. & O.P. & M & 27 & $\begin{array}{l}\text { Right knee anterior cruciate } \\
\text { ligament tear (Operated) }\end{array}$ & Athlete \\
\hline
\end{tabular}

For the assessment, the following were used: The WOMAC (Western Ontario and McMaster Universities) score (WOMAC Osteoarthritis Index, 2016), the joint and muscle assessment (Balint, 2007, p. 27), the functional index of the lower limb (Manole \& Manole, 2009, pp. 84-85).

Following the assessment, a functional diagnosis for each patient was established, and the following symptoms were observed: pain, edema, a pain reflex position of the injured limb, muscle hypertrophy and hypotonia in the thigh and calf, a stiffness of the knee joint post-immobilization during flexion, poor stability and coordination. The physical therapy intervention objectives were as follows: to diminish pain in the ligament and tendon insertions; to drain the edema; to shrink the scars; to improve the joint mobility; to correct the agonist-antagonist muscle imbalance; to improve muscle strength; to increase joint stability and controlled mobility; to improve the static and dynamic balance; to improve the dexterity.

What follows is a general treatment scheme, adapted for each subject.

In order to diminish pain and prevent tendinous, ligamentous and muscular adherences, deep tissue massage was applied to the extensor muscles of the knee (the quadricipital tendon, the lateral edges of the vastus muscles, the patellar tendon), to the internal lateral ligament, to the capsule of the superior fibular-tibial joint, and to the hamstrings, while for the reduction of the edema, the lymphatic drainage was used. In order to improve joint mobility, various techniques were introduced progressively in the treatment. Initially, the patient performed several active mobilizations of the knee, flexion-extension, in order to establish the existent degree of mobility, and not to injure certain capsular-ligamentous structures during the following techniques. There was a gradual progress toward passive-active mobilizations, then passive mobilizations up to the point of pain, obtaining this 
way a greater range of motion. The patient was put into lateral recumbent position, thus avoiding the action of the gravity on the injured limb.

The proprioceptive neuromuscular facilitation techniques were introduced in the treatment, using the following scheme: rhythmic initiation (RI) $\rightarrow$ hold-relax $(\mathrm{HR})$ the agonist and then the antagonist variant $\rightarrow$ contract-relax (CR), aiming to increase the knee flexion. In order to correct the muscle imbalances, agonistantagonist, and in order to improve muscle strength, the following facilitation techniques were used: slow reversal (SR), slow reversal hold (SRH), and agonistic reversals (AR), on the hypotonic muscle groups (quadriceps-hamstrings, abductoradductor muscles, plantar-dorsal flexor muscles).

In order to increase joint stability and to improve static and dynamic balance, the isometric contraction in the shortened area (ICS) $\rightarrow$ alternating isometrics (AIs) $\rightarrow$ rhythmic stabilization (RS) were used in several positions (lateral recumbent, bent knee, sitting on a gymball, quiet standing). The PNF techniques that were previously described were applied analytically, on each injured muscle group, and globally, on Kabat diagonals, over the entire pivot range of the knee. Also, in order to improve dexterity, resisted progression (RP) and normal timing (NT) were used in the quiet standing position. Normal timing aimed to rehabilitate the fine motor skills, the patient going through various applicative tracks, the movements being directed with manual resistance. Resisted progression was performed on various walking directions (forward, backward, sideways), the grips being on the hips and shoulders. During the intervention, the motor control stages were followed, and the techniques were adapted initially in the first sessions up to the point of pain, in order to avoid injuring the affected structures, then progressively up to the limit of pain endurance.

\section{Results and Discussions}

This sub-chapter analyzes the results recorded by the subjects, and calculates the averages of the results recorded after the initial and final assessment.

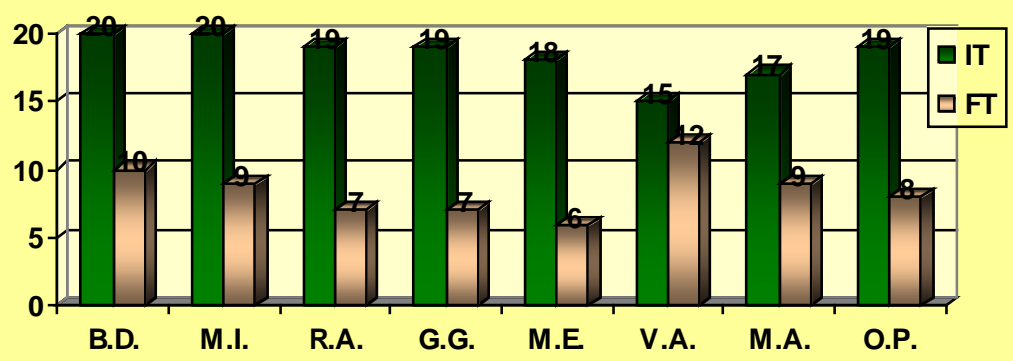

Figure 1. Graphical representation of the WOMAC Index results, for the group of subjects

The values recorded in the tables have emphasized several aspects regarding the effectiveness of the proprioceptive neuromuscular facilitation techniques in treating the post-immobilization sequelae. 
In regards to the WOMAC Index results, one can see in Figure 1 an improvement of functional parameters for entire group of patients, with an optimum score between 10-12 points. So, initial outcomes reveal that all patients had an exacerbated pain during walking on uneven ground, at stair climbing and during the night, the highest values being recorded by B.D and M.I patients (20 points). After applying custom treatment, with the decrease in postoperative symptoms and recovery of the motion control, we observe a decrease of the values for each patient, but the best outcomes were recorded by R.A, G.G., M.E. and M.A., with a difference of 12 points toward initial results.

\section{Results of the joint assessment}

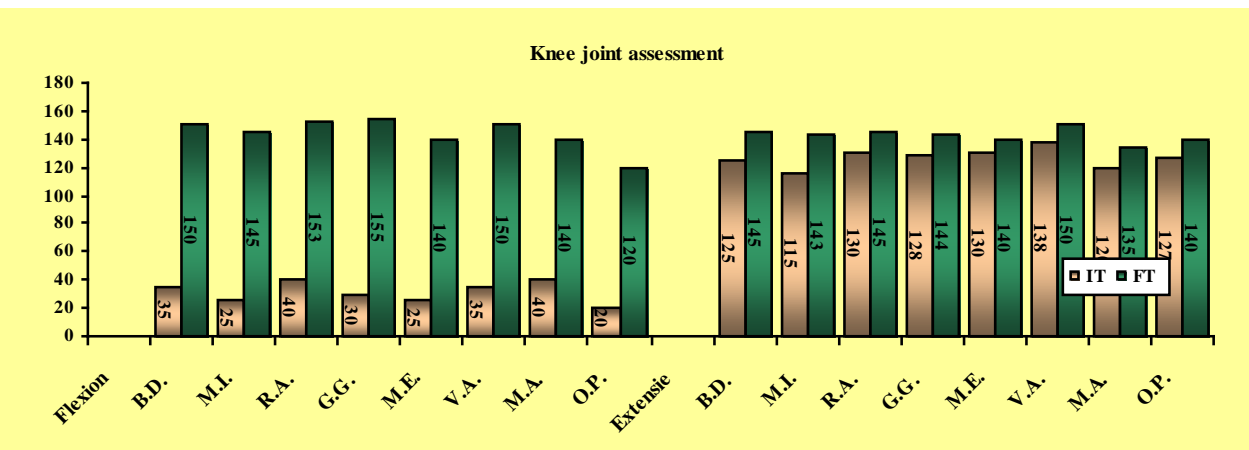

Figure 2. Knee joint assessment for the group of subjects

Table 2. Muscle assessment results

\begin{tabular}{|c|c|c|c|c|c|c|c|c|c|}
\hline \multirow{2}{*}{$\begin{array}{c}\text { Tested } \\
\text { muscles }\end{array}$} & \multirow{2}{*}{ Results } & \multicolumn{8}{|c|}{ Subjects / values } \\
\hline & & B.D. & M.I. & R.A. & G.G. & M.E. & V.A. & M.A. & O.P. \\
\hline \multirow{2}{*}{ Iliopsoas } & I.T. & 4 & 3 & 3 & 3 & 4 & 4 & 3 & 3 \\
\hline & F.T. & 5 & 5 & 5 & 5 & 5 & 5 & 5 & 5 \\
\hline \multirow{2}{*}{ Gluteus } & I.T. & 3.66 & 3.66 & 3.66 & 3 & 4 & 3 & 3 & 3.66 \\
\hline & F.T. & 5 & 5 & 5 & 5 & 5 & 5 & 5 & 5 \\
\hline \multirow{2}{*}{$\begin{array}{l}\text { Pertrochanteric } \\
\text { muscles }\end{array}$} & I.T. & 3.66 & 3.66 & 3.33 & 3 & 3 & 3.33 & 3 & 3.66 \\
\hline & F.T. & 5 & 5 & 5 & 5 & 5 & 5 & 5 & 5 \\
\hline \multirow{2}{*}{ Quadriceps } & I.T. & 3.66 & 3 & 3.66 & 3 & 4 & 3 & 3 & 3.66 \\
\hline & F.T. & 4.5 & 4.5 & 4.5 & 5 & 4.5 & 5 & 5 & 4.5 \\
\hline \multirow{2}{*}{ Hamstrings } & I.T. & 4 & 3 & 4 & 3 & 4 & 3 & 3 & 3.66 \\
\hline & F.T. & 4.5 & 4.5 & 4.5 & 5 & 4.5 & 5 & 5 & 4.5 \\
\hline \multirow{2}{*}{$\begin{array}{c}\text { Tensor fascia } \\
\text { lata }\end{array}$} & I.T. & 3 & 3 & 3 & 3 & 3 & 3 & 3 & 3 \\
\hline & F.T. & 5 & 5 & 5 & 5 & 5 & 5 & 5 & 5 \\
\hline \multirow{2}{*}{$\begin{array}{c}\text { Adductor } \\
\text { muscles }\end{array}$} & I.T. & 3 & 3 & 3 & 3 & 3 & 3 & 3 & 3 \\
\hline & F.T. & 4.66 & 4.5 & 5 & 5 & 5 & 4.66 & 4.66 & 5 \\
\hline \multirow{2}{*}{ Triceps surae } & I.T. & 3 & 3 & 3.66 & 3 & 3 & 3 & 3 & 3 \\
\hline & F.T. & 5 & 5 & 5 & 5 & 5 & 5 & 5 & 5 \\
\hline \multirow{2}{*}{$\begin{array}{l}\text { Tibialis } \\
\text { anterior }\end{array}$} & I.T. & 4 & 3 & 4 & 3 & 4 & 3 & 3 & 3 \\
\hline & F.T. & 5 & 5 & 5 & 5 & 5 & 5 & 5 & 5 \\
\hline \multirow{2}{*}{$\begin{array}{l}\text { Peroneus } \\
\text { muscles }\end{array}$} & I.T. & 4 & 3 & 4 & 3 & 4 & 3 & 3 & 3 \\
\hline & F.T. & 5 & 5 & 5 & 5 & 5 & 5 & 5 & 5 \\
\hline
\end{tabular}


Specific sequelae occurred after the orthosis immobilization, which led to a diminished mobility especially during flexion. Initially, during tests the data showed the mobility deficit. Thus, patients with the lowest flexion were M.E. and O.P. $\left(20-25^{\circ}\right)$, and M.I patient had the smallest mobility in both directions ( $25^{\circ}$ on flexion and $115^{\circ}$ on extension).

The final results recorded for each subject showed that at the end of the treatment, using particularly the facilitation techniques, the range has been improved during flexion movement with $113-115^{\circ}$ for R.A., B.D., M.E. and V.A, by $120-125^{\circ}$ for M.I, respectively for G.G. with $113^{\circ}$ and $100^{\circ}$ for M.A and O.P, and during extension movement with10-15 $5^{\circ}$ for R.A., M.E, V.A., M.A. and O.P., with $20^{\circ}$ for B.D, and $28^{\circ}$ for M.I.

Previously, the muscle assessment results were presented, showing an improvement of muscle strength up to the maximum value of 4.5 - 5 in the entire group, according to the manual muscle examination. By analyzing outcomes, we found that the lowest strength were recorded by M.I, G.G, and M.A. with values between 3-3,66 points, represented 50-70\% from entire strength, which means they were able to move their limb against gravity on the whole amplitude. After applying the recovery program, increasing the movement control, was recorded an increase until 4,5-5 points, representing $90-100 \%$ from entire strength, this fact being materialized by the ability of patients to move their limb in full amplitude, against gravity and maximum distal resistance.

\section{Results of the lower limb functional index testing}

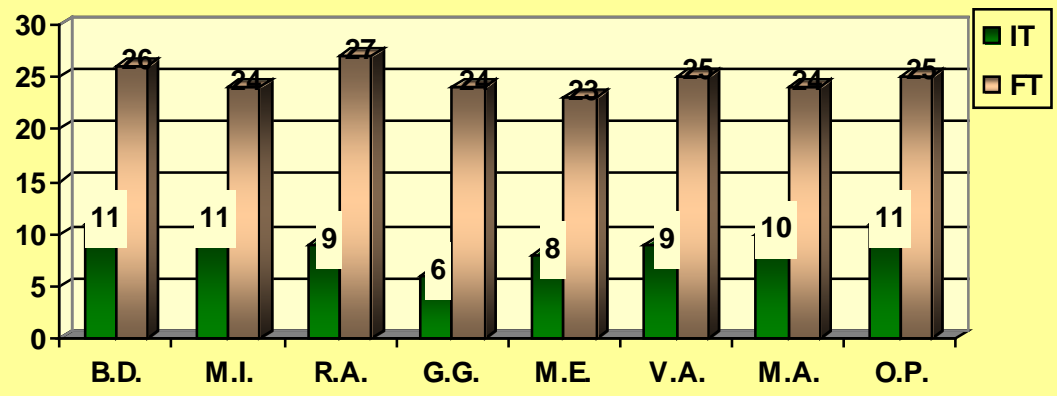

Figure 3. Graphical representation of the Functional Index results, for the group of subjects

Figure 3 illustrates the functional index of the injured lower limb, the data being the result of a calculation between all numerical indices for each item of the test. As seen above, the initial data are poor, which indicates sequelae in the limb, such as: pain or unease when standing up or during daily life activities, mobility deficit, joint instability on various surfaces, during walking or stair climbing, reduction of the walking perimeter. The final data shows a good progress, between 
23 and 27 points out of a maximum 29. The best progress was recorded by subject RA, with 15 points, followed by BD, with 15 points, and MI, with 13 points.

\section{Discussions}

Zalta (2008) published an article in the International Journal, "Therapeutic Massage and Bodywork" that proves the effectiveness of massage in reducing postligamentoplasty femoral-patellar pain. The symptoms of the anterior cruciate ligament tear are pain in the femoral-patellar joint and in the vastus medialis and vastus lateralis muscles. The treatment applied consisted in lymphatic drainage, myofascial release, and deep tissue massage. The tests used were: the pain scale, the muscle testing and the joint assessment. The massage therapy started 4 days after the arthroscopy and lasted 10 weeks.

The results confirm the hypothesis of the study, proving that "pain was reduced after 6 massage sessions, joint mobility has improved by 6 degrees, and the circumference of the knee has diminished by $2.75 \mathrm{~cm}$, due to the lymphatic drainage. The electromyography showed that muscle tone has increased after a few treatment sessions, the subjects being able to return to their pre-trauma physical activities (Zalta, 2008). Shaffer, Okereke, Esterhai and Elliott (2000) published an article in the "Physical Therapy" journal, proving the effects of the postimmobilization physical therapy intervention in patients with ankle and knee fractures.

The group of subjects consisted of 10 patients with ankle fractures after 8 weeks of immobilization. The muscle strength testing was done using the dynamometer, at various time periods - after 1 week, after 5, and after 10 weeks. After 10 weeks of physical therapy intervention the joint mobility has improved in all movements, and the reflex pain position was diminished.

Also, the muscle strength and endurance, and the controlled skills were significantly improved. Thus, the conclusion of the study was that the early use of physical therapy reduces post-immobilization sequelae, contributing to a fast rehabilitation of the patients (Shaffer et al., 2000).

\section{Conclusions}

At the end of the research, it can be said that the initial hypothesis was confirmed, this resulting from the study on the 8 cases that were presented.

The general conclusions that can be drawn from this study are the following:

The use of the Kabat method and of the proprioceptive neuromuscular facilitation techniques on the lower limb during the post-immobilization stage has had beneficial effects on the progress of the patients' health, shortening their rehabilitation time, reducing the risk of complications, and contributing to the consolidation of the positive results.

The physical therapy intervention had beneficial effects also on the mental state of the patients, because the rehabilitation was faster and they were able to return to their socio-professional activities faster. 


\section{References}

1. BALINT, T. (2007). Evaluarea aparatului locomotor, Iaşi: Pim, 27;

2. DE BOER, M.D, SELBY, A., ATHERTON, P., SMITH, K., SEYNNES, O.R., MAGANARIS, C.N., MAFFULLI, N., MOVIN, T., NARICI, M.V., \& RENNIE, M.J. (2007). The temporal responses of protein synthesis, gene expression and cell signalling in human quadriceps muscle and patellar tendon to disuse, Physiology, 585: 241-251;

3. GLOVER, E.I., PHILLIPS, S.M., OATES, B.R., TANG, J.E., TARNOPOLSKY, M.A., SELBY, A., SMITH, K, \& RENNIE, M.J. (2008). Immobilization induces anabolic resistance in human myofibrillar protein synthesis with low and high dose amino acid infusion, Physiology, 586: 6049-6061;

4. HVID, L., AAGAARD, P., JUSTESEN, L., BAYER, M.L., ANDERSEN, J.L., ORTENBLAD, N., KJAER, M., \& SUETTA, C. (2010). Effects of aging on muscle mechanical function and muscle fiber morphology during short-term immobilization and subsequent retraining, Appl. Physiology, 109: 1628-1634;

5. JOHNSTON, B.D. (2006). Merck, Traumatismele legate de sport, Bucharest: All, 2571;

6. JONES, S.W., HILL, R.J., KRASNEY, P.A, O'CONNER, B., PEIRCE, N., \& GREENHAFF, P.L. (2004). Disuse atrophy and exercise rehabilitation in humans profoundly affects the expression of genes associated with the regulation of skeletal muscle mass, FASEB, 18: 1025-1027;

7. KISS, I. (2002). Fizio-kinetoterapia şi recuperarea medicală în afecţiunile aparatului locomotor, București: Medicală, 160;

8. MANOLE, V., \& MANOLE, L. (2009). Evaluare motrică şi funcţională în kinetoterapie, Iaşi: Pim, 84-85;

9. SALTIN, B., \& GOLLNICK, P.D. (2011). Skeletal Muscle Adaptability: Significance for Metabolism and Performance, Comprehensive Physiology, 555-631;

10. SBENGHE, T. (2008). Kinesiologie Ştiinţa Mişcării, Bucureşti: Medicală, 196;

11. SHAFFER, M.A, OKEREKE, E., ESTERHAI, J.L.JR., \& ELLIOTT, M.A. (2000). Effects of immobilization on plantar-flexion torque, fatique resistance, and functional ability following an ankle fracture, Physical Therapy, 80(8): 769-780;

12. SIMON, R. (2006). Merck, Fracturi, entorse, luxaţii, Bucharest: All, 2571;

13. SOMMER, H.M., (1988), Patellar Chondropathy and apicitis and muscle imbalances of the lower extremities in competitive sports, Sports Medicine, 6(5): 386-394;

14. SULLIVAN, M.J., GREEN, H.J., \& COBB, F. (1990), Skeletal muscle biochemistry and histology in ambulatory patients with long-term heart failure, Circulation, 81: 518-527; 
15. ZALTA, J. (2008). Massage Therapy Protocol for Post-Anterior Cruciate Ligament Reconstruction Patellofemoral Pain Syndrome: A Case Report, International Journal of Therapeutic Massage \& Bodywork: Research, Education, \& Practice, 1(2): 11-21;

16. WOMAC OSTEOARTHRITIS INDEX. (2016). WOMAC® 3.1 Index Knee and Hip Osteoarthritis Index, http://www.womac.org/womac/index.htm.

\title{
Eficiența Facilitării Neuromusculare Proprioceptive Privind Îmbunătăţirea Controlului Motor de la Nivelul Membrelor Inferioare Postimobilizare
}

\author{
Popa Cristina-Elena ${ }^{1}$ \\ ${ }^{1}$ Universitatea "Vasile Alecsandri" din Bacău, Calea Mărășești 157, 600115, România
}

Cuvinte cheie : traumatism, sechele, mobilitate, stabilitate, abilitate

\section{Rezumat:}

Imobilizarea în aparat gipsat atrage după sine perturbări ale circulaţiei, alterări ale muşchilor, retracţii ale capsulei ligamentare şi aderenţe. Scopul prezentei lucrări îl reprezintă particularizarea unor metode şi tehnici în vederea diminuării sechelelor postimobilzare de la nivelul membrelor inferioare. Lotul de subiecţi a fost alcătuit din 8 pacienţi cu afecţiuni la nivelul genunchiului, studiul desfăşurându-se pe o perioadă de 10 luni de zile. Metodele de evaluare utilizate au constat în folosirea testelor pentru mobilitate, forţă, stabilitate şi abilitate. Intervenţia kinetoterapeutică a fost alcătuită dintr-o suită de metode şi tehnici care pe parcursul tratamentelor au fost particularizate în funcţie de simptomatologia pacienţilor. Concluzia generală, ce se poate extrage din studiul efectuat, este că, utilizarea facilitării neuromusculare proprioceptive la nivelul membrului inferior, faza postimobilizare, are efecte benefice asupra evoluţiei stării de sănătate a pacienţilor, perioadei de recuperare (în sensul scurtării acesteia), reduce riscul apariţiei complicaţiilor şi contribuie la consolidarea rezultatelor pozitive obţinute.

\section{Introducere}

Dintre structurile articulaţiei genunchiului, cel mai frecvent afectate de leziuni sunt ligamentele colateral medial şi încrucişat anterior. Cel mai frecvent mecanism pentru lezarea ligamentelor genunchiului este o forţă medială, spre interior, de obicei acompaniată de o rotaţie externă şi flexie (Johnston, 2006, p. 2571). În astfel de cazuri, ligamentul medial colateral este de obicei lezat, urmat de ligamentul încrucişat anterior şi apoi de meniscul medial. Următorul mecanism lezional ca frecvenţă este o forţă externă, afectând de obicei ligamentul colateral lateral, ligamentul încrucişat anterior, sau pe ambele. Forţele anterioare sau posterioare şi hiperextensia au de obicei ca rezultat lezarea ligamentelor încrucişate. Purtatul de greutăţi şi rotaţia în momentul predispun la leziuni ale meniscurilor (Simon, 2006, p. 2572). Două-trei săptămâni de imobilizare poate 
cauza pierderi de masă musculară de până la 5-10\%, asociate cu scăderea forţei de până la 10-20\% (Boer et al, 2007, p. 241; Glover et al., 2008, p. 6050). Sommer aduce în discuţie un studiu asupra importanţei musculaturii din jurul genunchiului în statica şi dinamica întregului corp.

Autorul a demonstrat prin măsurarea forţei musculaturii genunchiului în diverse poziţii ale corpului, influenţa mare a zonei cervicale, a pelvisului şi mai ales a zonei toracice şi lombare asupra motricităţii corpului (Sommer, 2002, p. 387). Saltin and Gollnick (2011) demonstrează că "după câteva săptămâni de antrenament apar modificări ale proprietăţilor fibrelor musculare, ceea ce înseamnă schimbare de tipologie. Invers, în condiţii patologice (ex. insuficienţă cardiacă) apar decondiţionări musculare datorită absenţei unui anumit nivel de activitate fizică care se traduce prin creşterea proporţiei de fibre tip II (b)" (Sullivan, Green, \& Cobb, 1990, p. 520).

Forţa musculară nu este o funcţie a tipului de fibră musculară decât indirect, în sensul că unele fibre au diametre mai largi, având mai multe miofibrile, deci mai multe punţi transversale (Sbenghe, 2008, p. 196).

O reabilitare rapidă şi eficientă a masei musculare şi a forţei este de 0 importanţă esenţială pentru pacienţii aflaţi în perioada postimobilizare ( et al., 2010, p. 1630), cu toate că există un număr mic de studii privind influenţa moleculară asupra masei musculare în această fază (Jones et al., 2004, p. 1025).

Kinetoterapia activă destinată refacerii forţei musculare, nu numai a cvadricepsului, ci şi a ischiogambierilor, devine din ce în ce mai puţin analitică şi mai mult globală, dirijată în sensul refacerii catenelor musculare ale membrului inferior. Se lucrează în lanţ muscular deschis, împotriva unei rezistenţe manuale şi cu folosirea din plin a elementelor de facilitare neuro-musculară periferică şi centrală (Kiss, 2002, p. 160).

Cunoscând deci debitele aferente excitatoare care converg către un grup de neuroni motori, ce efectuează contracţia unui anumit muşchi, folosind şi sursele stimulatoare de vecinătate, se poate întări răspunsul acestora, mărind astfel timpul potenţialului de membrană de la 0,5- 1 ms la 10-15 ms. Este ceea ce se întâmplă în metodele de facilitare proprioceptivă (Kabat \& McLeod, 1959).

\section{Material şi metode}

Ipoteza de la care am pornit în realizarea acestui studiu a fost următoarea: dacă aplicarea tehnicilor de facilitare neuromusculare proprioceptive (FNP) în tratamentul sechelelor postimobilizare de la nivelul membrului inferior, contribuie la îmbunătățirea controlului motor.

Cercetarea s-a efectuat asupra unui lot de 8 subiecţi de sex masculin, diagnosticaţi cu rupturi ligamentare la nivelul articulaţiei genunchiului, în urma cărora au suferit intervenţii chirurgicale. Imobilizarea, în aceste cazuri a fost realizată prin orteze reglabile, iar intervenţia kinetoterapeutică a început la aproximativ două-trei săptămâni postoperator.

Se observă din tabelul nr.1 că pacienţii au fost selectaţi din medii sociale diferite, vârste apropiate, fiecare beneficiind de aproximativ de 12-15 şedinţe de 
kinetoterapie, până la recuperarea aproape completă a controlului motor, efectuate cu o frecvenţă de trei pe săptămână, cu o zi sau două pauză, pentru a preveni oboseala musculară. În perioada de pauză, pacienţii au urmat un program de exerciţii fizice adaptat în funcţie de simptomatologie.

Metodele şi tehnicile aplicate pe parcursul tratamentului au fost atent particularizate şi individualizate în funcţie de reacţiile subiecţilor, atât la începutul tratamentului sau a şedinţelor, cât şi pe parcurs.

Tabel 1. Lotul de subiecţi

\begin{tabular}{|c|c|c|c|c|c|}
\hline $\begin{array}{l}\text { Nr. } \\
\text { crt. }\end{array}$ & Iniţiale & Sex & Vârsta & Diagnostic clinic & Profesie \\
\hline 1. & B.D & M & 38 & $\begin{array}{l}\text { Ligament încrucişat anterior cu } \\
\text { aspect de întindere şi ruptură parţială } \\
\text { genunchi stg. (Operat) }\end{array}$ & Operator IT \\
\hline 2. & M.I. & M & 42 & $\begin{array}{l}\text { Leziune ligament încrucişat anterior, } \\
\text { leziune condrală (fisură) patelară } \\
\text { genunchi dr. (Operat) }\end{array}$ & $\begin{array}{l}\text { Funcţionar } \\
\text { public }\end{array}$ \\
\hline 3. & R.A. & M & 35 & $\begin{array}{l}\text { Dezinserţia proximală a ligament } \\
\text { încrucişat anterior genunchi dr. } \\
\text { (Operat) }\end{array}$ & Comerciant \\
\hline 4. & G.G & M & 40 & $\begin{array}{l}\text { Ruptură de ligament încrucişat } \\
\text { anterior genunchi stg.(Operat) }\end{array}$ & Agent vânzări \\
\hline 5. & M.E & M & 35 & $\begin{array}{l}\text { Ruptură de ligament încrucișat } \\
\text { anterior genunchi stg.(Operat) }\end{array}$ & Manager \\
\hline 6. & V.A. & M & 36 & $\begin{array}{l}\text { Ruptură de ligament încrucișat } \\
\text { anterior genunchi dr.(Operat) }\end{array}$ & Electrician \\
\hline 7. & M.A. & M & 43 & $\begin{array}{l}\text { Ruptură de ligament încrucişat } \\
\text { anterior genunchi stg.(Operat) }\end{array}$ & Arhitect \\
\hline 8. & O.P. & M & 27 & $\begin{array}{l}\text { Ruptură de ligament încrucişat } \\
\text { anterior genunchi dr.(Operat) }\end{array}$ & Sportiv \\
\hline
\end{tabular}

Pentru evaluare, am utilizat: Scorul WOMAC (Western Ontario and McMaster Universities) (WOMAC osteoarthritis index, 2016), bilanţul articular, muscular (Balint, 2007, p. 27), Indicele funcțional al membrului inferior (Manole \& Manole, p.84-85).

În urma evaluării, am stabilit diagnosticul funcţional pentru fiecare pacient în parte, însă ca şi simptome privind lotul de subiecţi am remarcat: prezența durerii, a edemului, poziţie reflex antalgică a membrului inferior afectat, hipotrofie și hipotonie musculară pe regiunea coapsei și a gambei, redoare a articulației genunchiului postimobilizare pe mişcarea de flexie, stabilitate și coordonare deficitare. Obiectivele intervenției kinetoterapeutice au fost următoarele: diminuarea durerii de la nivelul inserțiilor ligamentare și tendinoase; drenarea edemului; asuplizarea cicatricilor; îmbunătătirea mobilității articulare; corectarea dezechilibrelor musculare, agoniști-antagoniști; îmbunătățirea forței musculare; creșterea stabilităţii articulare şi a mobilităţii controlate; îmbunătăţirea echilibrului static și dinamic; îmbunătăţirea abilităţii.

Î̉n continuare, am detaliat o schemă generală de tratament, pe care însă am 
adaptat-o pentru fiecare subiect în parte, urmând etapele controlului motor.

În scopul diminuării durerilor şi a prevenirii apariţiei aderenţelor tendinoase, ligamentare şi musculare am aplicat masajul transversal profund la nivelul aparatului extensor al genunchiului (tendonul cvadricipital, marginile laterale ale vaştilor, tendonul rotulian), al ligamentului lateral intern, pe capsula articulaţiei peroneo-tibiale superioare şi la nivelul muşchilor ischiogambieri, iar pentru reducerea edemului am folosit drenajul limfatic.

Pentru îmbunătăţirea mobilității articulare am introdus progresiv diferite tehnici în tratament. Iniţial, pacientul a executat câteva mobilizări active ale genunchiului pe flexie-extensie, pentru a afla gradul de mobilitate existent, și pentru a nu leza unele structuri capsulo-ligamentare în momentul utilizării următoarelor tehnici. Treptat, am trecut către mobilizările pasivo-active, şi apoi, progresiv, către mobilizări pasive până la apariţia durerii, obținându-se în acest mod un grad de amplitudine mai mare.

Pacientul a fost poziționat în decubit lateral, astfel evitându-se acțiunea gravitaţiei asupra membrului afectat. Am introdus în tratament tehnicile de facilitare neuroproprioceptive, utilizând următoarea schemă: iniţiere ritmică (IR) $\rightarrow$ relaxare-opunere (RO) varianta agonistică şi apoi antagonistică $\rightarrow$ relaxarecontracție (RC) cu scopul de creşte flexia genunchiului. Pentru corectarea dezechilibrelor musculare, agoniști-antagoniști, și pentru îmbunătățirea forței musculare am folosit următoarele tehnici de facilitare: inversare lentă (IL), inversare lentă cu opunere (ILO) și inversare agonistică (IA) pe grupele musculare hipotone (cvadriceps-ischiogambieri, abductori-adductori, flexori plantari-dorsali). Pentru a crește stabilitatea articulară și pentru a îmbunătăți echilibrul static și dinamic am realizat din diferite poziții (decubit lateral, cavaler servant, așezat pe un gymball, ortostatism), contracţia izometrică în zona scurtată (CIS) $\rightarrow$ izometria alternată $(\mathrm{IzA}) \rightarrow$ stabilizarea ritmică $(\mathrm{SR})$.

Aceste tehnici FNP descrise mai sus le-am aplicat atât pe schemă analitică, pe fiecare grup muscular afectat, cât și în schemă globală pe diagonale Kabat pe toată amplitudinea cu pivot genunchi. De asemenea, în scopul îmbunătățirii abilităţii, am utilizat progresia cu rezistenţă (PR) și secvenţialitatea normală (SN), din poziția de ortostatism. Secvențialitatea normală a vizat recuperarea motricităţii fine, pacientul urmând diferite parcursuri aplicative, mișcările fiind dirijate cu rezistență manuală.

Progresia cu rezistență s-a realizat pe diferite direcții de mers (mers înainte, înapoi, lateral), prizele fiind aplicate atât la nivelul bazinului cât și la nivelul umerilor. În cadrul intervenţiei, am respectat etapele controlului motor şi am adaptat tehnicile iniţial, în primele şedinţe până la apariţia durerii pentru a evita lezarea structurilor afectate, apoi progresiv, până la limita suportabilităţii durerii.

\section{Rezultate şi discuţii}

În acest subcapitol, au fost analizate rezultatele obținute de la întregul lot de subiecți și s-au calculat mediile aritmetice după evaluarea inițială și finală. Valorile consemnate în tabele au scos în evidență o suită de aspecte privind eficiența 
tehnicilor de facilitarea neuroproprioceptive în tratamentul sechelelor postimobilizare.

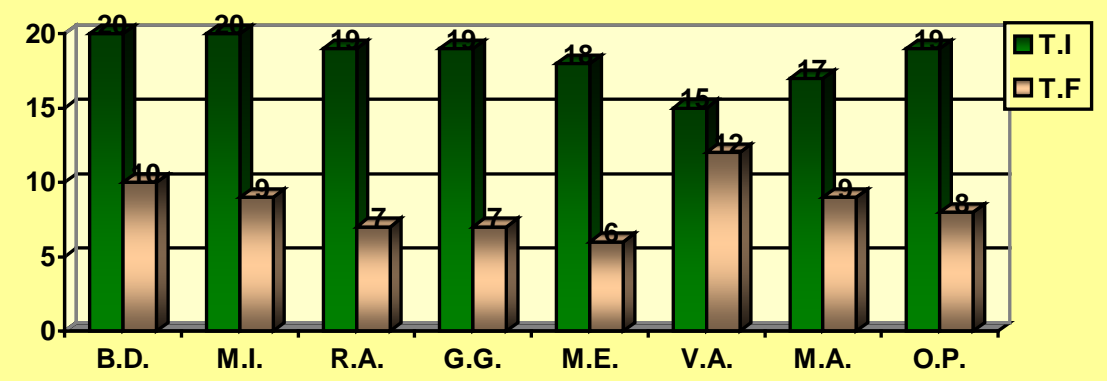

Figura 1. Reprezentarea grafică a rezultatelor Indexului WOMAC, lotul de subiecți

În ceea ce privește rezultatele Indexului WOMAC, se observă din figura nr.1 că subiecţii B.D. şi M.I. prezentau iniţial durere exacerbată în timpul mersului, la urcatul scărilor, noaptea, încadrată cu un maximum de 20 de puncte. La testarea finală, trei dintre subiecţi respectiv B.D., M.I.şi O.P.au înregistrat cea mai bună evoluţie cu o diferenţă de 10-11 puncte.

În ceea ce priveşte rezultatele Indexului WOMAC, se observă din figura nr.1 o îmbunătăţire a parametrilor funcţionali pentru întreg lotul de subiecţi, cu un punctaj optim cuprins între 10-12 puncte. Astfel, rezultatele iniţiale relevă faptul că, toţi subiecţii prezentau durere exacerbată în timpul mersului pe teren denivelat, la urcatul scărilor şi pe timpul nopţii, cele mai mari valori înregistrându-le pacienţii B.D. şi M.I. (20 puncte). În urma tratamentului particularizat, o dată cu diminuarea simptomatologiei postoperatorii şi refacerea controlului motor, se constată o scădere a valorilor pentru toţi subiecţii, însă cel mai bune rezultate au fost obţinute de pacienţii R.A., G.G., M.E. şi M.A., cu o diferenţă de 12 puncte faţă de testările iniţiale.

\section{Rezultatele bilanţului articular}

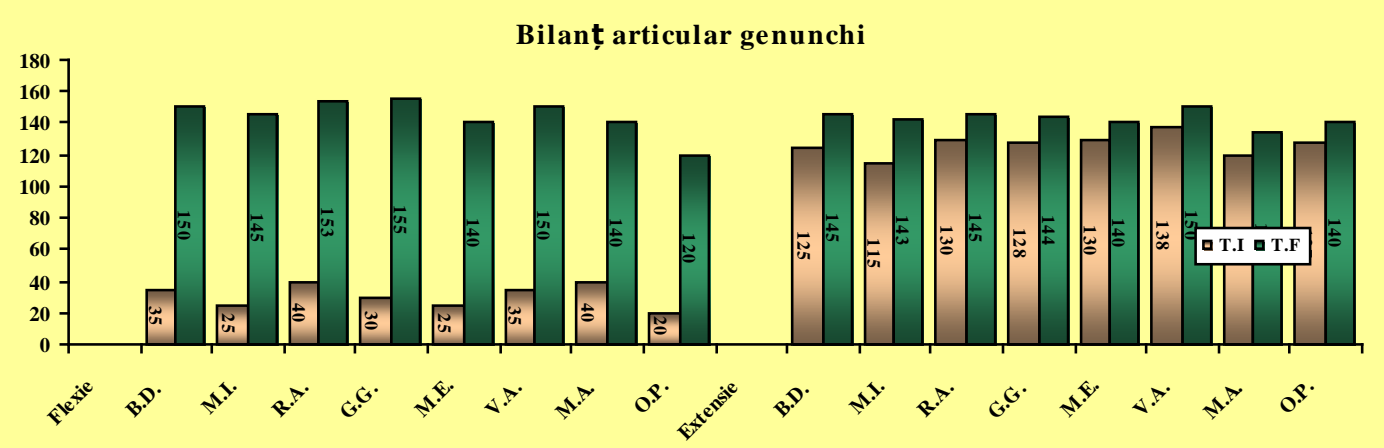

Figura 2. Bilanțul articular la nivelul genunchiului pentru lotul de subiecţi 
În urma imobilizării cu ajutorul ortezelor, s-au instalat sechelele specifice, ceea ce au condus la o diminuare a mobilităţii pe direcţia de flexie în special. Iniţial în urma testelor s-au obținut date ce atestau deficitul de mobilitate. Astfel, pacienţii cu cea mai redusă flexie au fost M.E. şi O.P. $\left(20-25^{\circ}\right)$, iar subiectul M.I. a avut cea mai redusă mobilitate pe ambele direcţii $\left(25^{\circ}\right.$ pe flexie şi $115^{\circ}$ pe extensie)

Rezultatele finale înregistrate pentru fiecare subiect, relevă faptul că, la sfârșitul tratamentului utilizându-se în mod particular tehnicile de facilitare specifice, amplitudinea s-a îmbunătățit pe mișcarea de flexie cu $113^{\circ}-115^{\circ}$ pentru R.A., B.D., M.E. şi V.A., $120^{\circ}-125^{\circ}$ pentru M.I., respectiv G.G. $113^{\circ}$ şi $100^{\circ}$ pentru M.A.şi O.P., iar pe extensie cu $10^{\circ}-15^{\circ}$ pentru subiecţii R.A., M.E., V.A., M.A. şi O.P., $20^{\circ}$ pentru B.D. şi $28^{\circ}$ pentru M.I.

Tabel 2. Rezultatele Bilanţului muscular

\begin{tabular}{|c|c|c|c|c|c|c|c|c|c|}
\hline \multirow{2}{*}{$\begin{array}{c}\text { Muşchii } \\
\text { testaţi }\end{array}$} & \multirow{2}{*}{ Rezultate } & \multicolumn{8}{|c|}{ Subiecţi / valori } \\
\hline & & B.D & M.I. & R.A. & G.G. & M.E. & V.A. & M.A. & O.P. \\
\hline \multirow{2}{*}{ Iliopsoas } & T.I & 4 & 3 & 3 & 3 & 4 & 4 & 3 & 3 \\
\hline & T.F & 5 & 5 & 5 & 5 & 5 & 5 & 5 & 5 \\
\hline \multirow{2}{*}{ Fesieri } & T.I & 3,66 & 3,66 & 3,66 & 3 & 4 & 3 & 3 & 3,66 \\
\hline & T.F & 5 & 5 & 5 & 5 & 5 & 5 & 5 & 5 \\
\hline Pelvi- & T.I & 3,66 & 3,66 & 3,33 & 3 & 3 & 3,33 & 3 & 3,66 \\
\hline trohanterieni & T.F & 5 & 5 & 5 & 5 & 5 & 5 & 5 & 5 \\
\hline \multirow{2}{*}{ Cvadriceps } & T.I & 3,66 & 3 & 3,66 & 3 & 4 & 3 & 3 & 3,66 \\
\hline & T.F & 4,5 & 4,5 & 4,5 & 5 & 4,5 & 5 & 5 & 4,5 \\
\hline \multirow{2}{*}{$\begin{array}{l}\text { Ischio- } \\
\text { gambieri }\end{array}$} & T.I & 4 & 3 & 4 & 3 & 4 & 3 & 3 & 3,66 \\
\hline & T.F & 4,5 & 4,5 & 4,5 & 5 & 4,5 & 5 & 5 & 4,5 \\
\hline \multirow{2}{*}{$\begin{array}{c}\text { Tensorul } \\
\text { fasciei lata }\end{array}$} & T.I & 3 & 3 & 3 & 3 & 3 & 3 & 3 & 3 \\
\hline & T.F & 5 & 5 & 5 & 5 & 5 & 5 & 5 & 5 \\
\hline \multirow{2}{*}{ Adductori } & T.I & 3 & 3 & 3 & 3 & 3 & 3 & 3 & 3 \\
\hline & T.F & 4,66 & 4,5 & 5 & 5 & 5 & 4,66 & 4,66 & 5 \\
\hline \multirow{2}{*}{ Triceps sural } & T.I & 3 & 3 & 3,66 & 3 & 3 & 3 & 3 & 3 \\
\hline & T.F & 5 & 5 & 5 & 5 & 5 & 5 & 5 & 5 \\
\hline \multirow{2}{*}{$\begin{array}{c}\text { Tibial } \\
\text { anterior }\end{array}$} & T.I & 4 & 3 & 4 & 3 & 4 & 3 & 3 & 3 \\
\hline & T.F & 5 & 5 & 5 & 5 & 5 & 5 & 5 & 5 \\
\hline \multirow{2}{*}{ Peronieri } & T.I & 4 & 3 & 4 & 3 & 4 & 3 & 3 & 3 \\
\hline & T.F & 5 & 5 & 5 & 5 & 5 & 5 & 5 & 5 \\
\hline
\end{tabular}

Anterior, sunt prezentate valorile Bilanţului muscular ce arată o îmbunătătire a forței musculare aproape de maximum la nivelul întregului lot, conform examinării musculare manuale. In urma intervenţiei şi a imobilizării, toţi subiecţii au prezentat dezechilibre musculare pe întreg membrul inferior afectat.

Analizând toate rezultatele, se constată că forţa cea mai redusă iniţial au avut-o pacienţii M.I., G.G. şi M.A. cu valori între 3 şi 3,66 puncte, reprezentând 50-70\% din totalul forţei, ceea ce înseamnă că erau capabili să efectueze mişcări pe toată amplitudinea împotriva gravitaţiei, însă fără mijloace rezistive. 
In urma intervenţiei, prin creşterea controlului motor se constată pentru întreg lotul de subiecţi, o creştere până la 4,5-5 puncte, reprezentând 90-100\%, fapt concretizat prin abilitatea pacienţilor de a efectua mişcările pe toată amplitudinea, împotriva gravitaţiei şi a unei rezistenţe maximale cît mai distal situată.

\section{Rezultatele Testării indicelui funcţional al membrului inferior}

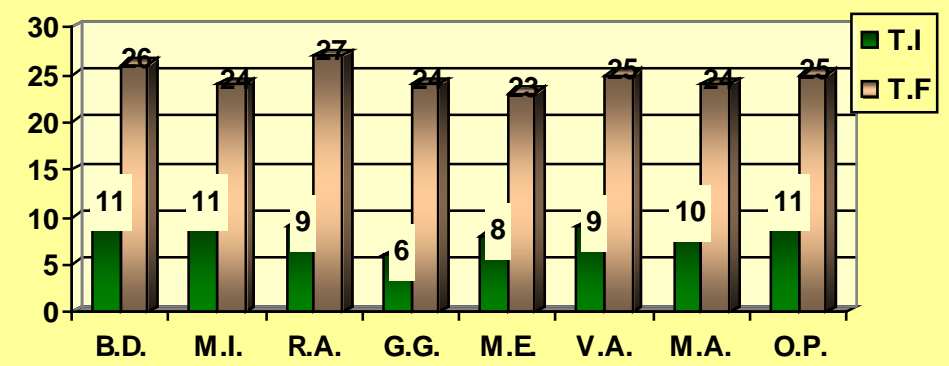

Figura 3. Reprezentarea grafică a rezultatelor Indicelui funcţional, lotul de subiecți

Figura 3 ilustrează Indicele funcțional al membrului inferior afectat, datele fiind obținute în urma unui calcul al tuturor indicilor numerici specifici fiecărui item din test. După cum se observă mai sus, datele inițiale sunt mai slab cotate, ceea ce indică sechele la nivelul membrului cum ar fi: durere la ridicarea în ortostatism sau în activităţile cotidiene, deficit de mobilitate, instabilitate articulară pe diferite suprafețe, în timpul mersului sau urcatul scărilor, reducerea perimetrului de mers. Din datele finale reiese un progres destul de bun cuprins între 23-27 puncte, luând în calcul faptul că punctajul maxim este 29. Progresul cel mai mare 1au înregistrat subiecţii R.A. şi B.D., de 15 puncte, urmat de M.I., cu 13 puncte.

\section{Discuții}

Zalta (2008) a publicat un articol în Revista „Therapeutic Massage and Bodywork" prin care demonstrează eficienţa masajului în diminuarea durerii postligamentoplastie femuro-patelară. $\mathrm{Ca}$ şi simptomatologie, ruptura ligamentului încrucişat anterior determină durere în articulaţia femuro-patelară şi la nivelul muşchilor vastului medial şi lateral. Tratamentul aplicat a constat în drenaj limfatic, masaj miofascial şi transversal profund.

Testele utilizate au fost: scala de durere, testing-ul muscular şi bilanţul articular. Intervenţia prin masaj a început la 4 zile post-chirurgical şi a durat 10 săptămâni. Rezultatele confirmă ipoteza studiului, demonstrându-se că "durerea s-a redus după 6 şedinţe de masaj, mobilitatea articulară s-a îmbunătăţit, iar circumferinţa genunchiului s-a diminuat cu $2,75 \mathrm{~cm}$. La electromiografie s-a constatat că tonusul muscular a crescut după câteva şedinţe de tratament, subiecţii revenind la activităţile fizice dinaintea traumatismului (Zalta, 2008). 
Shaffer, Okereke, Esterhai, and Elliott (2000) au publicat un articol în revista „Physical Therapy”, demonstrând efectele intervenţiei kinetoterapeutice postimobilizare la pacienţii cu fracturi la nivelul gleznei şi piciorului. Lotul de subiecţi a fost constituit din 10 pacienţi cu fracturi la nivelul gleznelor după 8 săptămâni de imobilizare.

Testarea forţei musculare a fost realizată cu dinamometrul, în diferite perioade - după 1 săptămână, 5 şi apoi 10 săptămâni. După 10 săptămâni de kinetoterapie, s-a îmbunătăţit mobilitatea articulară pe toate mişcările, iar poziţia reflex antalgică a fost diminuată. De asemenea forţa, rezistenţa musculară şi abilităţile controlate au fost semnificativ crescute. Astfel, concluzia studiului este că, aplicarea precoce a kinetoterapiei, reduce sechelele postimobilizare, contribuind la refacerea mai rapidă a pacienţilor (Shaffer et al., 2000).

\section{Concluzii}

În urma cercetării efectuate și a rezultatelor obținute, se poate afirma că ipoteza stabilită iniţial s-a confirmat, acest lucru rezultând din studiul asupra celor 8 cazuri prezentate.

Concluziile generale, ce se pot extrage din studiul efectuat, sunt următoarele:

Utilizarea metodei Kabat și aplicarea tehnicilor de facilitare neuroproprioceptive la nivelul membrului inferior, faza postimobilizare, au avut efecte benefice asupra evoluției stării de sănătate a pacienţilor, perioadei de recuperare (în sensul scurtării acesteia), au redus riscul apariției complicațiilor și au contribuit la consolidarea rezultatelor pozitive obținute.

Intervenţia kinetoterapeutică a avut efecte benefice şi asupra psihicului pacienţilor, întrucât recuperarea s-a realizat mai rapid şi aceştia şi-au putut relua activităţile socio-profesionale într-un timp mai scurt. 